\title{
The Bravery in the Nun Movie Directed By Cordin Hardy
}

\author{
Maulani Pangestu' ${ }^{1}$, Istihayyu Buansari ${ }^{2}$, Dwi Indah Lestari ${ }^{3}$ \\ 1,2,3 Universitas Bina Sarana Informatika \\ 1'maulani.mpu@bsi.ac.id, ${ }^{2}$ istihayyu.iyb@bsi.ac.id, dwiindah780@yahoo.com

\begin{tabular}{ccc}
\hline Diterima & Direvisi & Disetujui \\
$02-09-2021$ & $17-09-2021$ & $28-09-2021$ \\
\hline
\end{tabular}

\begin{abstract}
The purpose of research is to find out what courage is and how many types of courage. This research was conducted by using a film as a source entitled The Nun which was released in 2018, directed by Corin Hardly. The author wants to analyze the causes of courage. The author chooses the film The Nun and the main character as the object of this study. The method of this research is descriptive qualitative. The results of this study are: (1) Causes of courage from the main character based on Rahman's theory: Confidence, Situational Demands, Altruism and Emotional and Cognitive Resources (2) Actions of courage from the main character: St.Carta Monastery of Romania, he left the Substitute for searching for truth, proving the Truth (3) The moral values of the film: truths that teach how to deal with our lives because humans must always struggle and do not give up in any situations. Courage is one of the most important qualities we must have. Having courage can help us achieve extraordinary things in social life. We also need courage to give good and positive things to those around us.
\end{abstract}

Key Words: The Nun, Movie, Bravery

Abstrak - Tujuan dari penelitian adalah untuk mengetahui apa itu keberanian dan ada berapa macam tipe keberanian itu sendiri. Film berjudul The Nun yang dirilis pada tahun 2018, disutradai oleh Corin Hardly. Penulis ingin menganalisa tentang penyebab keberanian. Penulis memilih film The Nun dan menggunakan karakter utama sebagai objek dari penelitian ini. Metode Penelitian yang digunakan adalah metode deskriptif kualitatif. Hasil dari penelitian ini adalah:(1) Penyebab keberanian dari karakter utama berdasarkan teori Rahman: Percaya diri,Tuntutan Situasional, Altruisme dan Sumber Daya Emosional dan Kognitif (2) Tindakan keberanian dari karakter utama: Biara St.Carta Rumania, dia meninggalkan Vantikan untuk mencari kebenaran dan membuktikan Kebenaran (3) Nilai-nilai moral dari film : kebenaran yang mengajarkan kita untuk berpikir dalam menghadapi hidup kita karena manusia harus selalu berjuang dan tidak menyerah dalam hal apapun. Keberanian adalah salah satu sifat yang sangat penting yang harus kita miliki. dengan memiliki keberanian maka bisa membantu kita mencapai hal-hal luar biasa dalam hidup bermasyarakat. Kita juga butuh keberanian supaya bisa memberihal -hal yang baik dan positif bagi orang sekitar.

\section{KataKunci: The Nun, Film, Keberanian}

\section{INTORDUCTION}

Literature can be interpreted as a source of reference used in various activities in the world of education or other activities, the most common term used to refer to creative works of imagination, including poetry, drama, film or movie, fiction and nonfiction. As stated by (Smallwood 2001) Literature is a work of high art which lack human interest dies, for its human interest to last and human interest change the language of a work has to have life, and its form has to please. It means that literature is a work of the deepest meaning of an art. Also, the life of a human being is involved here as the experience.

Film is one the literary work that together between audio and visual to present something to be interested to watch, hence, people will have a good mood when they see film and don't get bored. Film is always offering something new to the audiences. Thus, people feel enthusiast and always be joyful when they watch it. Film as a media is affected by outside of other media because audio and visual work well together in making the viewers do not feel bored and easier to remember because the format is interesting. According to (Ramrao 2016) film on the other hand mostly employ the spoken aspects of communication like sounds. Sounds are dominated in film making. Written and Spoken Communication is a very important source through which human beings gain wisdom throughout their life". It means movie is an illustration of a collection of images that are broadcast through video and produce an entertainment. 
Film is a complex and unique art form of communication media which influence all segments of society. Film can also give intense feelings and involve people directly and the real world out there and in one's life. Moral messages can have positive and negative impacts. Viewers can capture those messages in the film easily. There are also those who have difficulty in this matter. Moreover, they watch film only for more entertainment purposes.

(Kusumaningrum 2015) said "Movie", "motion pictures", "moving pictures" all these phrases suggest the central importance of motion in the art of film. Cinema derives from the Greek word for "movement", as do the words kinetic, kinesthesia and choreography-term usually associated with the art of dance". The purpose of the theory above that is moving picture, which has a collection of some of the images driven by the purpose of art in order to entertain the people who watch it.

Meanwhile (Melih 2016) argues, There are several types of movies that people watch regularly. Horror movie is one of movie that people watch regularly, it's a kind of movie entertaining audiences with stirring fear and horror. The story always involves death and the supernatural.

While (Wasinki 2016)) stated that horror movies are one of the move that people glad to watch regularly in cinema. Its mention that for the horror version, Dutch angels are most commonly used to indicate a negative, dark shift in tone for a character, whether it be the victim who is about to be killed or the murderer who is beginning to show his or her true color.

Horror films fall into several genres, namely: comedy horror, action horror, thriller horror, etc. Of all the horror genres above the horror thriller and action horror that are most demanded by everyone because they present fear and tension to the audiences. Usually script and plot contains various characters and events.

The aim of horrors movie is to terrorize the viewers by showing various scenes with scary characters so that when watching the film we don't just remain silent but fell the tensions throughout the film. This is what makes horror films famous plots and events are generally different from daily life. Sometimes, horror movies give surprises and terrors that can mark the hearts of the audiences and can give its own impressions to the viewers. It is not common anymore that even horrors films are still in great demand today. Starting from the production, story arrangement, story lines and even the effects displayed are not low class.
In order to enjoy watching horror movie, movie goers must have courage to be brave enough to do so. According to (Linley et al. 2006) that there are three types of courage: physical, moral, and vital.

While in factors of bravery (Arumsari 2018) mention that the component of character consists of three, namely moral knowing, moral feeling and moral action. These three components are needed so that children are able to understand, feel and work on the values of virtue.

(Peterson and Seligman 2004) focus on character strengths and virtues. Character strength is the psychological element that forms virtues. The purpose of the above explanation is that each virtue is composed of several character strengths, it is very good for a person's character to have various strength characters from each virtue.

(Woodard and Pury 2007) Three of the four factors of courage (perseverance, integrity, and courage) are ranked which means placing them in the top five forces, along with hope, the power of transcendence, and kindness, the strength of humanity. Various strengths are associated with higher public courage (actions that are brave for anyone), lower personal courage (actions that dare only in the context of the life of certain actors), or both. Thus, the presence of strength seems to be more strongly associated with general courage than with personal courage. From statements above, bravery that is very important to shape the character in working on the values of virtue.

This research analyze a horror movie about the courage of Sister Irene that reveals the death of the devil Nun name Valak. Even in horror films, it teach us good things, one of is the courage to do something by putting aside of the fear ourselves which we can channel it into the fantasies, dreams, hopes and goals.

This research also discusses a character named Sister Irene. As mention by (Temmermen 2018) we define character very roughly as the relatively stable moral, mental, social and personal traits which pertain to an individual. (Greenstein 2018) said that Character is both stable and continually developing over time" from Greenstein and Holland's research, the characters are individuals who have a stable role and evolve over time. Meanwhile, (Alwisol. 2018) mention that "Character is an illustration of behavior which emphasizes on right-wrong and good-bad values both explicitly and implicitly. 
The Nun is one of horror movie that shows the act of bravery by the main character. This study reveals the cause of bravery, the act of main character bravery and moral value of the movie. The film was released in 2018 and was played by famous actor and actress, Taissa Farmiaga and Demian Bichin.

\section{RESEARCH METHODOLOGY}

The method applied in this research is descriptive qualitative as well as dialogue analysis to describe the bravery cause and the bravery of the main character.

Mention by (Creswell 2014) qualitative research is a research to explore and understand the meaning of which for some individuals or groups considered social or humanity problems. It explain that qualitative research involve essential approach, such as asking questions and procedures, collecting data specifically toward participants, analyzing data inductively which starts specific themes to general themes, and interpret data.

Data is not limited to the collection and compilation of data but includes analysis and interpretation of the meaning of the data. Then data will become a discourse and conclusion in logical, practical, and theoretical thinking. The writer collects the entire data and materials with a variety of resources. Such as books, journals, articles. And other references from internet sources. And also the primary resources of this paper are still the movie itself by watching the movie several times to understanding the plot. The writer pays attention in every segments, narrations, gestures, and dialogues or act of bravery is towards the main character in the movie. Taking notes, categorize and put forward findings that are considered important and interesting.

\section{FINDINGS AND DISCUSSION}

In this part the researcher display findings of bravery and then analyze. The data was taken from the scenes that considered as the act of bravery.

\section{Cause of Bravery}

There are 4 causes or factors which are causes someone show courage based on (Rachman 1990) theory:

\subsection{Self Confidence}

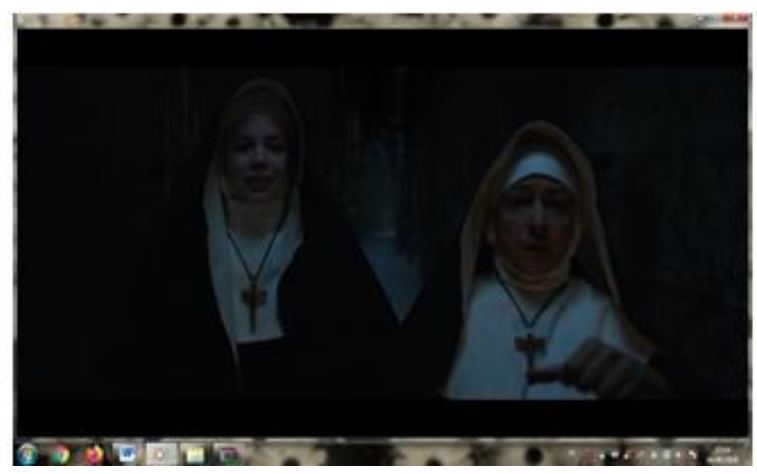

Figure 1

\section{Sister Victoria and Sister Jessica enter the hallway to enter the haunted door}

Scene 01.40-02.53

\section{Details conversation of figure 1}

$\begin{aligned} & \text { Sister Victoria } \\ & \text { this?" } \\ & \text { Sister Jessica }\end{aligned} \quad$ : "What do we have to do

Sister Jessica walked a little towards the door. With the strength of full courage, Sister Jessica opened the old door. When the door opened, it was very clear that the room was very dark. One firefly did not illuminate the place. And again, Sister Victoria was afraid and doubtful about what Sister Victoria did.
Sister Victoria : : Are you sure that thing will save us?".
Sister Jesisca : "Rest assured, Sister"

In the scene on the picture above, Sister Victoria and Sister Jessica are preparing to open the old and haunted door and fight Valak. He enters with all the courage in him.

According to the data, Sister Victoria and Sister Jessica are preparing to fight Valak and open the haunted and old door. Sister Victoria and Jessica believed that she did this then the monastery was free of evil spirits.

Sister Jessica said "Be assured, Sister," she showed that Sister Jessica had the confidence and courage to fight Valak. The more confident people are, the less fear people experience. Battle is one of the factors or causes of Bravery. Based on all the dialogues, Sister Jesisca is shown as having the confidence that makes her willing to deal with dangerous situations because of her strength abilities.

\subsection{Situational Demands}




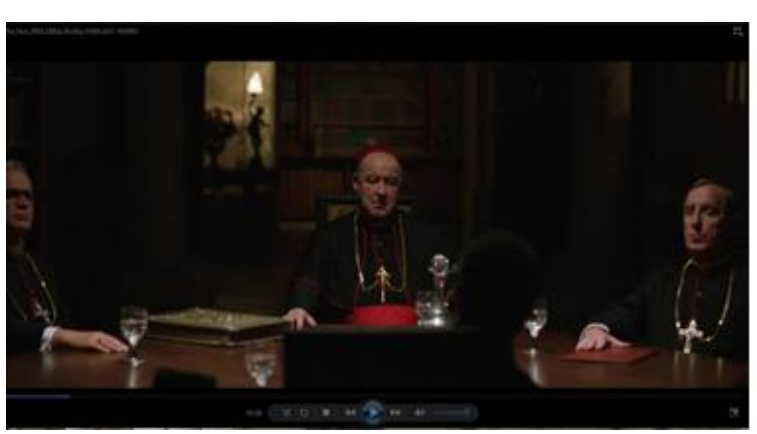

Figure 2

\section{Father burke argues with Cardinal conroy}

\section{Scene : 07.50-08.41}

Details conversation of figure 2

\begin{tabular}{|c|c|}
\hline Bishop & : "Father Burke?" \\
\hline Father Burke & : "Yes, bishop?" \\
\hline Bishop & $\begin{array}{c}\text { : "When was the last time you were } \\
\text { here? 6-7 years ago, right?" }\end{array}$ \\
\hline Father Burke & $\begin{array}{l}\text { : "After my priesthood when the } \\
\text { war was over" }\end{array}$ \\
\hline ishop & : "We appreciate that you came \\
\hline
\end{tabular}

Then they came to a meeting room where there was already a Cardinal Conroy (Cardinal $=$ high official of the church) and several people beside him.

Cardinal : : "Father Burke, sit down!"

"There is news that a nun committed suicide in a Romanian mountain monastery"

Father Burke : "Yes, suicide is a very big sin. But

Cardinal : "But this news must not shake our faith"

Father Burke : "You kept something from me"

Cardinal : "What's the matter? Why do you say that?"

Father Burke : "All this information has not been valid. This is at the Vatican, all cases must be clear!"

Cardinal : "Tell you what, father. In this rare case, we don't need secrets "Here are your travel documents, documents and contacts about the man who found the nun. He lives in Biertan village, his village is around "
Bishop

: "You better talk to him first, if you want"

Cardinal : "In the document there are also prospective nuns who will help you""Because this is sensitive and has become a nun's rule, she is also no stranger to her territory"

In this scene Father burke met with a Cardinal Conroy. Cardinal Conroy told us that a monastery in the Romanian mountains had killed himself and Father Burke was sent to investigate the strange phenomenon related to Catholic teachings. Unofficially they call it the pursuit of miracles. And he was instructed also by the vail to determine whether this place was still holy or not.

Father Burke said, "Yes, suicide is a very big sin. But I don't think that's the reason we gathered ". It showed that Father Burke did not believe that the nun's death was due to suicide and there were other reasons why he was sent to investigate the death of the nun at $\mathrm{Ct}$. Romanian News. Father burke is suspicious of Cardinal Conroy as if he knows something that Father Burke does not know. And he was insisted by waiting to quickly complete the mission to save the monastery. It is indicated that situational demands influence Father Burke's courage

\subsection{Altruism}

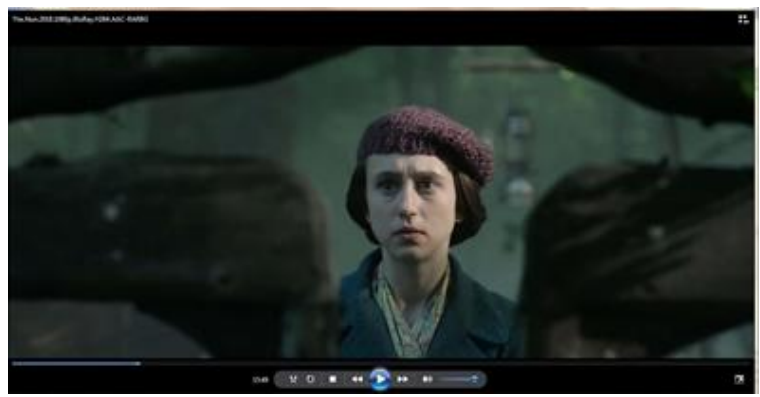

Figure 3

Frienchie talk with Father Burke

Scene 15.49-16.22

\section{Detail conversation of figure 3}

Sister Irene : "May I ask, Father? What is your

usual job? "

Father Burke : "The Church is calling me if it needs an investigation into the strange phenomena associated with Catholic teaching. Unofficially they 
call it" The pursuit of miracles.

Sister Irene : "I think we are here investigating suicides."

Father Burke : "Yes, that is part of our investigation. I was also ordered by the vail to determine whether this place is still holy or not.

Frienchie : "I can help with that, Father."

In this scene, Frienchie takes Father Burke and Sister Irene to the Romanian monastery by using horses therefore they could investigate suicides cases in that area.

Frienchie said "I can help with that, Father." We know that he helped Father Burke and Sister Irene even though he was afraid to go to the monastery. He could not leave Father Burke and Sister Irene alone. So here he is brave because he chose a sense of altruism.

\subsection{Emotional and Cognitive Resources}

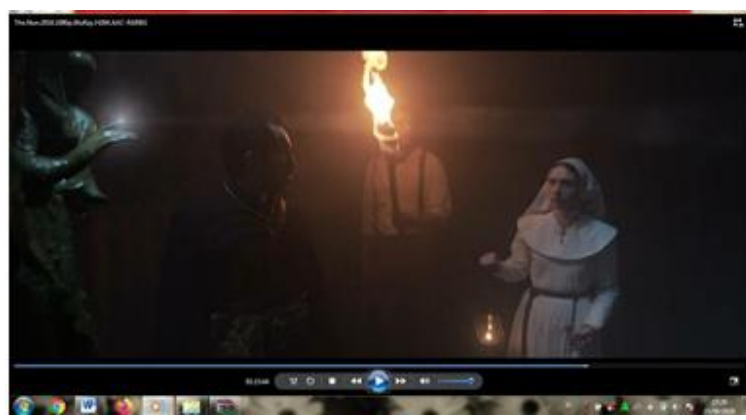

Figure 4

Father Burke is happy to find the blood of Christ

Scene: 01.15.44 - 01.16.59

Detail conversation of figure 4

Frienchie : : "Nothing here."

Sister Irene : : "There must be, they say this key

Frienchise opens the inheritance door"

Father Burke

: "It could not be here."

Sister Irene

"The door is not here, do you not see the nurse?"

Father Burke : : Mary has shown the way."

In this scene, the courage of Sister Irene, Frienchie and Father Burke who went to the gate of the catacombs to get the blood of Christ to close the gates of the devil to hold the evil spirits in the city.
Father Burke said "Mary has shown the way." It shows the joy of Father Burke who found the blood of Christ at the gate of the catacombs and he wanted to quickly complete the mission of waiting for the place to return to the holy monastery and no evil spirits to disturb the monastery.

\section{Main Character's Bravery Act}

\subsection{St. Carta Monastery, Romania}

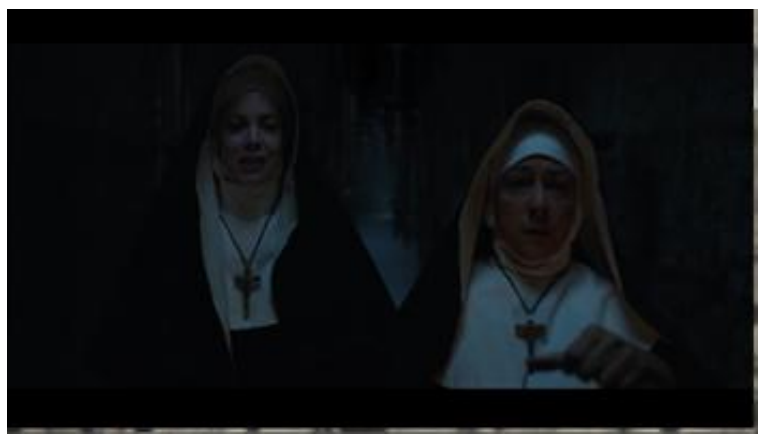

Figure 5

Sister Jessica entered an unholy place alone

Scene 01.40-02.53

\section{Detail conversation of figure 5}

Sister Victoria

this?".

Sister Jessica
: "What do we have to do

: "We have no other choice (surrender)".

Sister Jessica walked a little towards the door. With the strength of full courage, Sister Jessica opened the old door. When the door opened, it was very clear that the room was very dark. One firefly did not illuminate the place. And again, sister Victoria was afraid and doubtful about what Sister Victoria did.
Sister Victoria
:"Are you sure that thing will save us?".
Sister Jesisca

From the above scene Sense Sister Jessica wants to help because she wants the convent to be free of evil spirits. he went down the aisle filled with hundreds of wooden crosses. The crosses were hung and also placed around the wall, there were crosses along the alley. They walked towards an unholy place.

Sister Jessica said "we have no other choice" she decided to go alone into the hallway with the strength of courage that full of Sister Jessica opened the door and prepared to fight valak alone. 
2.2. Leaving Vatican

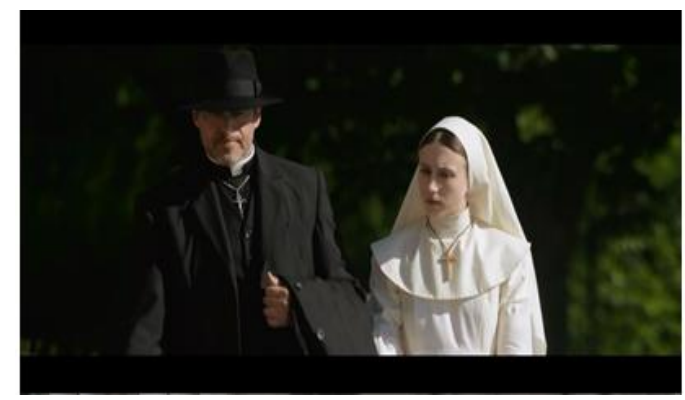

Figure 6

Sister Irene met Father Burke Scene : 10.14 -10.41

\section{Detail conversation of figure 6}

Sister Irene : "That region?" Father Burke : "Yes.

\section{Romania"}

Sister Irene : "But, I haven't been there before" Father Burke : "Really?

Sister Irene : "Yes, there must be a mistake. Sorry

if you came here in vain

Father Burke : "No no, you don't need to apologize

that every decision made by the Vatican has a purpose. I believe they

have a reason for choosing you

From the picture above, Sister Irene met someone named Father Burke and they talked about her planned trip to the Abbey of St. Chart due to the task of the church's investigation.

Father Burke said, "No, no, you don't have to apologize, every decision made by the Vatican has a purpose. I believe they have a reason for choosing you. Here, it showed that they were sent to leave the Vatican city to investigate the suicide case that occurred in a Romanian monastery and they decided to leave.

\subsection{Finding the truth}

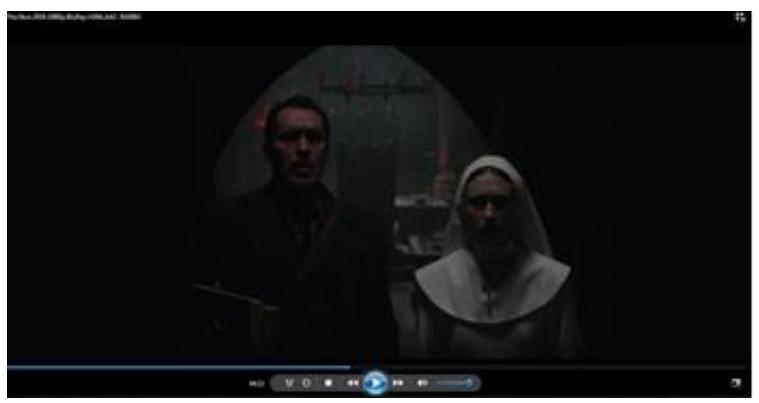

Figure 7

Father Burke and Sister Irene met the head nurse in search of evidence

Scene: 42.11-53.59

\section{Detail conversation of figure 7}

Father Burke : "Head nurse! As requested yesterday, we want to talk to the nuns, it

looks

Sister Irene : : "I will look for Sister Head"

Father Burke : "All right, accept that! Find out About that key! This seems to be very influential on our research. Be careful, Sister!

Sister Irene : Surely Father

From the picture above Father Burke who wanted to meet the head nurse together with Sister Irene who wanted to ask the truth about the nun's death that occurred in the abbey but the presence of Father Burke and Sister Irene did not seem to be accepted. And they went around the monastery looking for evidence.

Father Burke said, "Okay, accept that! Find out about that key! This seems to be very influential on our research. Be careful, Sister!". This shows that Father Burke and Sister Irene wanted to find out the truth about the key. Sister Irene walked down the monastery to get a hint about the mysterious key and she met with Sister Oana who told her about the history of the monastery and why it was no longer sacred. Father Burke and Sister Irene who want to find evidence so that the case of one solved and then can look for further evidence to break the mystery.

\subsection{Proving the truth}

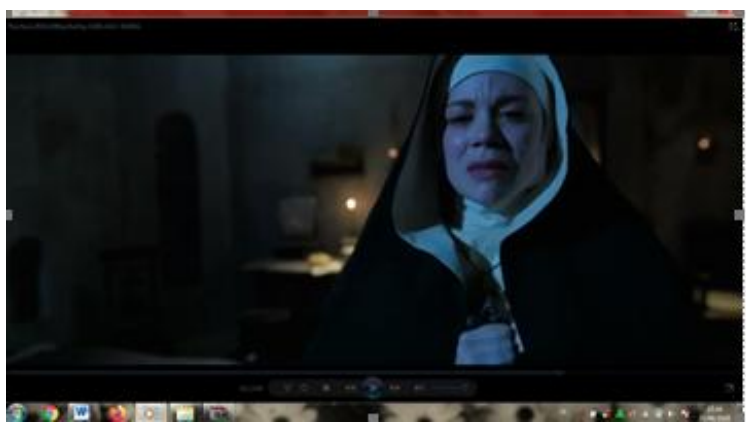

Figure 8

Suster irene talk with father burke

Scene : 01.12.20 - 01.13.36 


\section{Detail conversation of figure 8}

Sister Irene : "No longer the tormented, Father.

This place is no longer sacred, we have got the answer.

Suddenly Sister Oana's corpse woke up and stuck the sharp cross in her hand into Father Burke's waist.

Frienchie : "What should we do, Father? Father Burke : "Take my bag, Sister! Take the holy

Hurry cross. then pour holy water,

$$
\text { up! " }
$$

Sister Irene rushed over and gave the holy cross to Father Burke.

Father Burke : Lay him down! Cover his face! "

The cross began to emit fire, and Father Burke would not be able to withstand the heat and release the cross from his grasp.

Frienchie : "I think it was an emergency. We are

too late, the devil is free

Sister Irene : "No! Demons possess human souls so

that they can enter this world.

Father Burke : "Sister Victoria was the last nun here

and she committed suicide. Sister

\section{Irene : :He did not commit suicide. He sacrificed, so that the devil did not take his life.}

Frienchie : "I don't understand what you say, Sister, but I think we need to get out of here quickly.

Sister Irene : "We can't leave here?"

Frienchie : "Why not?"

Sister Irene : "We must close the gates of the devil

$$
\text { to hold the evil spirit" }
$$

The scene above is Father Burke, Sister Irene and Frienchie approached Sister Oana's body covered in white cloth. And Sister Oana's body turned into a very old corpse. the corpse of Sister Oana suddenly woke up and stuck a sharp cross which she held onto Father Burke's waist.

Sister Irene said "She did not commit suicide.

He sacrificed, so that the devil did not take his life."That means that Sister Irene has discovered the truth that Sister Victoria sacrificed her life not because of fear but rather she sacrificed so that the devil did not take his life and he protected himself from evil spirits.

\section{Moral Value}

The moral values that can be taken from the Nun Film are about courage and truth. This film shows the main character, it is said of a burke father who was quite famous for things that smelled supernatural and an exorcism sent by the Vatican cathedral to investigate a sacred monastery in the area of Romania, he and Sister Irene who had the strength of the magic inserts they possessed.

Sister Irene and Father Burke teach us to be thinking in facing our lives as humans must always struggle and not give up in matters of anything.

Courage is one of the most important qualities we have. Fear can prevent us from doing many things, but courage can help us achieve extraordinary things. In social life, we also need courage in order to be able to give positive things to those around us.

\section{CONCLUSION}

After discussing the courage in the The Bravery in the Nun Movie directed bye Cordin Hardly, the following conclusions can be drawn:

Based on Rahman's theory, he explains that there are 4 types of courage contained in the film in the film nun occur when the story takes place Data places and fives are the first cause is the confidence of Sister Jessica who entered the unholy place to fight valak. The second cause is the siteical response from the vail who ordered the father to investigate the mysterious death at the monastery. The third is a sense of frienchie altruism that helps the father of Burke and Sister Irene in investigating the deaths in the city. The last is the emotional and cognitive resources of the burke father who was delighted to have found the blood of Christ at the gate of the catacombs.

From the results of the analysis, there are four types of courage that can be seen in the main the characters from the Nun. The first act of courage is the desire of Sister Jessica who entered the unholy place alone. The second act of courage, Father Burke and Sister Irene, left behind to investigate the mysterious death that had occurred in Romania. The third act of courage was Sister Irene and Father Burke searching for the truth of the death that occurred in the convent. The fourth 
act of Sister Irene's courage in proving the courage that the abbey's death was not due to suicide but protecting herself from evil spirits.

The audiences of the film can get moral values related to courage and truth. The moral values are that taught us to think of our lives because humans must always struggle and do not give up in any situations. This film makes us realize that courage is one of the most important qualities we have. Having courage can help us achieve extraordinary things. In social life, we also need courage in order to be able to give something positive to those around us.

\section{REFERENCES}

Alwisol. 2018. "Social Relationship of Main Character in Fantastic Beast and Where to Find Them Film (By J.K. Rowling). Repository."

Arumsari, Cucu. 2018. "Kekuatan Karakter Dan Kebajikan Dalam Bimbingan Dan Konseling." Kekuatan Karakter Dan Kebajikan Dalam Bimbingan Dan Konseling 2:1-5.

Creswell. 2014. Research Design.

Greenstein, \&. Holland. 2018. "Social Relationship of Main Character in Fantastic Beast and Where to Find Them Film (By J.K. Rowling)."

Kusumaningrum, Maria Asumpta Deny. 2015. "Using English Movie as an Attractive Strategy to Teach Senior High School Students English as A Foreign Language." Language and Language Teaching Journal 18(01):11-18. doi: 10.24071/llt.2015.180102.

Linley, Alex P., Stephen Joseph, Susan Harrington, and Alex M. Wood. 2006. "Positive Psychology: Past, Present, and (Possible) Future." Journal of Positive Psychology 1(1):3-16.
10.1080/17439760500372796.

Melih, \&. Rafika. 2016. There Are Several Types of Movies That People Watch Regulary 17ed.

Peterson, Christopher, and Martin E. P. Seligman. 2004. Character Strengths and Virtues: A Handbook and Classification. Vol. 42.

Rachman, S. 1990. Fear and Courage 2nd Edition. New York: Freeman \& Co.

Ramrao, T. N. 2016. "No Title." Movie 22.

Smallwood, P. 2001. A History of English Literature. Vol. 51.

Temmermen, \&. Boas. 2018. "Social Relationship of Main Character in Fantastic Beast and Where to Find Them Film."

Wasinki, \&. Marguerite. 2016. "No Tit). Romantic Comedy and Horror Films: A Study of What Makes a Genre. Romantic Comedy and Horror Films: A Study of What Makes a Genre. Le."

Woodard, Cooper R., and Cynthia L. S. Pury. 2007. "The Construct of Courage: Categorization and Measurement." Consulting Psychology Journal 59(2):135-47. doi: 10.1037/10659293.59.2.135. 